УДК 378.016:811.111

DOI: https://doi.org/10.35619/iiu.v0i9.17

Yevheniia Protsko

$\mathrm{PhD}$ in Pedagogy, Associate Professor, Associate Professor at the English Language and Methodology Department, Pavlo Tychyna Uman State Pedagogical University, Uman, Ukraine ORCID: 0000-0002-8806-4919, e-mail: janeprotsko@gmail.com

\title{
BLENDED LEARNING: A NEW TECHNOLOGICAL ERA IN EFL TEACHING
}

\begin{abstract}
The article deals with the new method in teaching English as a foreign language. Today it is easy to have the Internet connection everywhere: in different educational and social settings, coffee shops, public transport, shops, classrooms etc. This article attempts to investigate the usage of the Internet and computer technologies in the process of teaching English as a foreign language, as at present to go with the times it is impossible for a teacher to neglect the interests and requirements of the students. It shows new opportunities for a teacher at English classes: modern platforms and web sites, social networks, blogs help not only share the information, make a lesson mobile-friendly, but motivate students in studying a foreign language. The article also shows the problem of the obsessive use of computer technologies which does not provide human-to-human contact, which may limit teacher's opportunities for communicative activities which are extremely necessary while studying a foreign language. The combination of IT and traditional modes are the elements of blended learning which is underlined to be the most effective method in teaching English as a foreign language. Thus, it is clearly the blended learning that is of extreme use today because of it clear and even combination of computer assisted language learning technologies and live communication with students. The information helps us to determine several characteristics for a successful foreign language teacher which among others (communicative, sociolinguistic, sociocultural and pragmatic) include methodical competence. That prove the urge necessity if using IT in general and blended learning in particular in the work of English as a foreign language teacher.
\end{abstract}

Key words: blended learning, English as a foreign language teaching (EFL teaching), computer assisted language learning technologies, social network, blog.

Formulation of the problem. Among educators, students and young Internet users online teaching is accepted as a viable component in teaching and learning. Thus blended learning as the combining of online and face-to-face learning is becoming a commonplace in many higher education institutions all over the world. In developing countries blended learning is known to be in its early stages and not without its challenges. Ukraine is one of them that bring the problem of media education on a new step of EFL teaching. Technological media have the potential to broaden the scope of resources available in teaching and to enhance the language learning experience (Wright, 2017).

Today in Ukraine there is the problem of rapid "knowledge aging" and the need for processing a large amount of information, thus, the country needs new professionals with modern knowledge and competencies. In order to achieve this 
goal, our educators created new types of learning which combine past achievements and valuable past experience and new information technologies. Here we mean the term "blended learning" which is used for characterizing a methodology that combines online learning, traditional learning and independent student work.

Blended learning forces us to consider the characteristics of digital technology, in general, and information communication technologies (ICTs), more specifically. Floridi (2014) suggests an answer proffered by Alan Turing: that digital ICTs can process information on their own, can also communicate information to each other, without human intervention, but as linked processes designed by humans (Floridi, 2014 , p. 30). We perceive our world more and more in informational terms, and not primarily as physical entities. Increasingly, the educational world is dominated by information and our economies rest primarily on that asset. So our world is also blended, and it is blended so much that we hardly see the individual components of the blend any longer (Dziuban, Graham, Moskall, Norberg and Sicilia, 2018).

The term 'blended learning' is a relatively new term. Various definitions of blended learning exist, and commonly in higher education, it is known as a combination of traditional face-to-face teaching and on-line teaching. Researchers however, have pointed to the complexities involved in accurately defining blended learning. Oliver and Trigwell (2005) argued that the focus should be on teaching rather than learning. Garrison and Kanuka (2004, p.96) note "virtually limitless design possibilities and applicability to so many contexts" as confounding a definition, and settle on an experiential focus, citing "integration of classroom faceto-face learning experiences with on-line learning experiences" as their definition (Dziuban, Graham, Moskall, Norberg and Sicilia, 2018).

Analysis of recent research on the problem. The problem of media education and IT learning has been substantially learnt by many scholars: American researchers A. Diozed, A. Mol, K. Northenstreg investigated the creation and development of social networks in the world. The Ukrainians also pay attention to this problem. T. Arkhipova, N. Osipova, and M. Lvov assert that the social networks as the main tool of educational process organization. V. Bykov underlines the psychological and pedagogical peculiarities of social servers in education, the connection of media education with the studying process.

Presenting the main material. Here it is necessary to mention Computer Assisted Language Learning technologies. However, some researchers question aspects of its suitability for higher education and language teaching. Levy also cautioned against it underlining technology integration requirements may not "meet the pedagogical aspirations of faculty and local needs, such as those required in L2 teaching and learning" (Levy, 2009, p. 779). We believe how to teach may be equally as important as what to teach for online language lessons. As noted by Clark and Mayer (2011, c. 19), an overload of text, audio, and visual input can be detrimental to learning, as can a lack of input. The fact to be considered as negative is the lack of verbal and non-verbal cues that may enrich teacher-student communication, particularly in language learning. Gestures, body language, and other audible cues enhance classroom communication and point to understanding or the lack of it.

As seen above, research on blended learning and its success is much and varied. Although there appears to be no definitive consensus in literature as to the value of blended learning (Wright, 2017) it is the one that deserves further study and defines the aim of this study as to explicate the importance of using blended learning 
in English classes, to characterize the influence of computer assisted language learning technologies as its main part on the formation of students' knowledge and skills.

In general, it is the question of e-learning in EFL teaching which is understood as the use of electronic media information and IT in education. It can be used in or out of classroom, self-paced or with the teacher or instructor guidance. It is often used as a mean of distance learning. It is urging to underline that it was in 1960s when in Illinois University, the USA; they decided to use computers in teaching students (Golnaz and Chalak, 2014, p. 2). Many years have passed since, but we still turn to the method to be widely and successfully implemented in all spheres of our lives, including education. That shows the problem is still vital and important to be investigated.

Another aspect that the article touches upon is one more phenomenon within computer assisted language learning technologies - network society. Some scientists consider its rise in communication society, thus, today networks, especially social ones, are playing a substantial role in our lives: networks easily connect people or groups of people according to their interest; they can acquire and create new communicational structures independently, which are difficult for traditional institutions; they can participate in the organization of social communities. In the digital age, the principles of media education are the same as they have always been, but the existence of cyberspace is adding new and challenging questions. The role of a teacher has been greatly changed, as there has appeared an accepted new critical pedagogy. We may emphasize the important challenges on evaluating the right information for one's needs and synthesize what one believes as being useful knowledge (What is Media Education?).

Thus, it is obvious to estimate the ambiguity and wide use of the term 'social network', the main notion of which is known as an integrated structure consisting of central elements and their connections - social web. But today when there appeared a wide network of social services we may find narrower interpretation - 'web service which gives opportunity for communication of big group of people and their combination in virtual communities according to the interests (Лобовікова, 2011). Here their peculiarity appears - the possibility to make content, do business, political and educational activities by the users themselves.

Different types of social networks - public (with open access) or close (for coworkers of the organization only or the students of a separate educational institution, faculty, or group) - improve educational functions; students can communicate and complete tasks of the subject.

Another peculiarity to be mentioned about the use of social networks in education is sociability - the ease feeling while communicating. Its basis is the feeling of trust, the possibility to ask a question privately. It is proved by the native researches who determine it as 'a possibility of an individual to keep a number of contacts while showing the optimal use of them - the information and resources interchange (Данько, 2012; Лещенко, 2011).

Here we also underline blogs as a component of modern technological tool in EFL teaching. Though blogs are integral element for any Internet user, teachers barely appreciate them as an educational tool. It is inevitably to happen at any school or with any teacher if not to recognize various pedagogical possibilities concerning use of blogs through file management, use of video, images and all kind of benefits relating interaction and communication. 
We understand blogs as web logs that are updated on a regular basis by their author. They can contain information related to a specific topic or used as daily diaries about people's personal lives, political views, or even as social commentaries. Blogs give the user an opportunity to write content that is unique to him and his activity. They also give an occasion to interact with the visitors while promoting who you are and what you do (Graham, 2006). At protection blogs as a tool of EFL teaching we define the fact while the students in this study enjoy reading views expressed by other bloggers, they exhibit a lack of a sense of belonging to a community of learners by not contributing their own views freely. It also coincides with teaching language and literature, which enhance reading comprehension and writing.

Thus, the above techniques can be useful, it is important to note that they are just tools and not the objective itself. They are not for all classes and need to be made an integral part of the course design. However, the uses of modern computeroriented modes as a learning tool seem to be low-cost with high-returns. Whatever research should to be done or how they can more effectively be used, it is a given that technology will continue to influence learning and teaching in every sphere of our lives. One should also not forget the problem of overuse of computer assisted language learning technologies that may lead to the loose of students' interest to the subject. There is also a necessity to be given good computer knowledge to get good results in blended learning (Процько, 2018).

To conclude, we have identified a few demerits of integrating IT platforms and modes into a teaching school environment. Still, we cannot deny the many advantages of e-learning. The virtual classes aim at stimulating informative interest to the language; making a class creative; contributing to students' team work. The bottom line here is that any institution that wants to offer online classes should be ready to invest in a good virtual classroom and learning management system.

The question of using IT platforms and computer environment is rather disputed. Any educator who wants to be in pace with the world educational changes has to use the new Internet tools (IT platforms, media tools, social networks, blogs etc.) to involve students in studying English, as they are the future of all the educational establishments. At the same time it is urge to remember some disadvantages web-enhanced instruction can bring when used in teaching English as a foreign language. As Sarah Johnson says, unfortunately, while studying distantly many people are programmed to multi-task when they're on the computer. This could lead to skimming articles or starting videos that turns into background noise as they try to complete another project at the same time which reduces the productivity of their work (Johnson, 2017). It is also embarrassing for some when they cannot ask a teacher for clarification in real time. Others might require lessons that are more hands-on, visual, or auditory than what a teacher may offer on his platform. Finally, it does not provide human-to-human contact, which may limit teacher's opportunities for team-building and role-playing activities, brainstorming, or discussion.

Conclusions and prospects for further researches. That is why we consider it is impossible to rely only on computer assisted language learning technologies while teaching English. We have to supplement it with in-person classroom-style training on as-needed basis that proves of the emerge use of blended learning in EFL teaching. Thus, the study proves more research needs to be conducted, examining 
different modern modes, methods and forms in teaching English, including fully online and blended learning environments.

\section{REFERENCES:}

Wright, B. (2017). Blended Learning: Student Perception of Face-to - Face and Online EFL Lessons. Indonesian Journal of Applied Linguistics, 7(1), pp. 64-71.

Floridi, L. (2014). The 4th Revolution: How the Infosphere is Reshaping Human Reality. Oxford: Oxford University Press.

Dziuban, C., Graham, C., Moskal1, P., Norberg, A. and Sicilia, N. (2018). Blended Learning: the New Normal and Emerging Technologies. International Journal of Educational Technology in Higher Education, 15(3), pp. 1-16.

Oliver, M., and Trigwell, K. (2005). Can "Blended Learning” be Redeemed? eLearning. pp.17-25.

Garrison, D. and Kanuka, H. (2004). Blended learning: Uncovering its Transformative Potential in Higher Education. The Internet and Higher Education, 7, pp. 95-105.

Levy, M. (2009). Technologies in Use for Second Language Learning. The Modern Language Journal, Focus Issue, [online] Volume 93, pp. 769-782. Access mode: http://www.jstor.org/stable/25612273

Clark, R. and Mayer, R. (2011). E-learning and the Science of Lnstruction. San Fransisco: Pfeiffer.

Golnaz, J. and Chalak, A. (2014). The Use of Internet in English Language Learning: Practices, Attitudes and Challenges of the Learning. Advances in English Language and Literature, 1(2), pp. 1-6.

What is Media Education? Available URL: https://www.medialiteracyweek.ca/about/what-is-media-education/ [Accessed 2014]

Lobovikova, O. (2011). Sotsialni merezhi yak fenomen informatsiinoho suspilstva [Social Networks as a Phenomenon of Informational Society]. Visnyk Lvivskoho universytetu, 5, ss. 154-160. [in Ukrainian].

Danko, Yu. (2012). Fenomen sotsialnykh merezh $u$ konteksti stanovlennia $i$ rozvytku merezhevoho suspilstva [The Phenomenon of Social Networks in the Process of Web Society Development]. Kharkiv. s. 53-61. [in Ukrainian].

Leshhenko, A. (2011). Social'nye seti kak mehanizm konstruirovanija kommunikacii $v$ sovremennom obshhestve [Social Networks as a Mechanism of Comminication Construction in Modern Society]. Kandydat fylosofskykh nauk. Piatyhorsk. [in Russian].

Graham, C. (2006). Blended Learning Systems: Definitions, Current Trends and Future Directions. San Francisco: Pfeiffer. pp. 3-21.

Protsko, Y. (2018). Blogs as a Modern Method in EFL Teaching. V: Konkurentospromozhnist vyschoi osvity Ukrainy $v$ umovakh informatsiinoho suspilstva. Chernohiv. s. 27-29. [in Ukrainian].

Johnson, S. (2017). The Advantages and Disadvantages of a Virtual Learning Environment. Access mode https://www.knowledgeanywhere.com/resources/articledetail/the-advantages-and-disadvantages-of-a-virtual-learning-environment. [Accessed 2017]

Floridi, L. (2008). A Defence of Informational Structural Realism. Synthese, 161(2), pp. 219-253. 


\title{
ЗМІШАНЕ НАВЧАННЯ: НОВА ТЕХНОЛОГІЧНА ЕРА У НАВЧАННІ АНГЛІЙСЬКОЇ МОВИ ЯК ІНОЗЕМНОЇ
}

\author{
Процько Євгенія \\ кандидат педагогічних наук, \\ доцент, доцент кафедри англійської мови та методики ії навчання \\ Уманського державного педагогічного університету імені Павла Тичини, \\ м. Умань, Україна \\ ORCID: 0000-0002-8806-4919, \\ e-mail: janeprotsko@gmail.com
}

\begin{abstract}
Анотація. У статті йде мова про новий підхід у навчання англійської мови як іноземної. Сьогодні тотальна інформатизація суспільства призводить до широкої популяризації новітніх методів навчання з використання інтернет та комп'ютерних ресурсів. Тому недивним $\epsilon$ той факт, що інтернет тісно втиснувся в наше повсякденне життя. Його можна знайти скрізь: в освітніх та громадських установах, кафе, транспорті, магазинах, навіть на зупинках міського транспорту. Поява розгалуженої системи інтернету та соціальних мереж як його невід'ємної та беззаперечно головної складової примушує змінюватися іншу, класичну, сферу життя - освіту. Саме тому сучасному вчителю нагально потрібно переглянути свої методи та засоби навчання. У дослідженні звертається увага на можливості використання змішаного навчання, яке надає вчителю нові можливості на уроках англійської мови: сучасні медіа та інтернет платформи, соціальні мережі, блоги тощо. Ці засоби тепер допомагають не лише поділитися нагальною освітньою інформацією, зробити урок «мобільним», а й мотивувати студентів до вивчення іноземної мови. Їх поєднання разом із традиційними методами навчання складає природу змішаного навчання, яке розглядається як найефективніший метод у навчанні англійської мови як іноземної. Стаття також підкреслює іншу сторону використання IКТ - його надмірність на уроці, яке не залишає можливостей для особистого, «живого» спілкування, може обмежити залучення студентів до комунікативних та групових видів роботи, адже останні $є$ надзвичайно важливими формами вивчення іноземної мови. Таким чином, сьогодні саме змішане навчання $\epsilon$ надзвичайно потрібним через його прозорість, комп'ютерну та інтернет спрямованість, разом із живим спілкуванням. Усе вищезазначене надає нам право визначити головні характеристики успішного вчителя англійської мови, серед яких (комунікативна, соціолінгвістична, соціокультурна та прагматична) не останне місце посідає методична компетентність. Все це підтверджує надзвичайну важливість у роботі вчителя англійської мови як іноземної використання комп'ютерно-орієнтованого навчання в цілому та змішаного навчання зокрема.

Ключові слова: змішане навчання, навчання англійської мови як іноземної, технології комп'ютерно-орієнтованого навчання, соціальна мережа, блог.
\end{abstract}

Стаття надійшла до редакиії 27.03.2019 p. 